\title{
Study of Pulmonary Hypertension and Left ventricular diastolic dysfunction in Patients of Sickle Cell Anaemia
}

\author{
Sanjay Varma ${ }^{1}$, Archana Toppo ${ }^{2}$, Animesh Choudhary ${ }^{3}$ \\ ${ }^{1,2}$-Associate Professor, ${ }^{3}$ - Resident, Department Of Medicine, Pt. J.N.M. Medical College And Dr. B.R.A.M. \\ Hospital, Raipur (C.G.)
}

\begin{abstract}
Background: Sickle Cell Disease(SCD) is a complex disorder with multi-organ complications. Cardiovascular abnormalities are well-recognized complication in SCD with cardiac enlargement and systolic murmurs being the most common findings. Multiple pathologic and clinical studies have shown that patients with pulmonary hypertension and diastolic left ventricular dysfunction represent a particularly high-risk subgroup. These cardiopulmonary complications contribute to a markedly low functional capacity and associated high risk of both sudden death and severe multi-organ dysfunction in SCD patients. The aim of study was to assess prevalence of Pulmonary hypertension and Left ventricular diastolic dysfunction by using $2 D$ Echocardiography in the patients of sickle cell anemia.

Material and Methods: This study was conducted in the Department of Medicine, Pt. Jawaharlal Nehru Memorial Medical College and Dr. B.R.A.M. Hospital, Raipur (C.G.) among the patients presenting in O.P.D. and admitted in medicine ward from Dec. 2013 to Sep. 2015. A total of 100 patients were taken fulfilling the inclusion criteria for the study. Detailed clinical history was recorded and all patients underwent complete clinical examination. Hb electrophoresis and $2 D$ Echocardiography of all patients were done.

Results: In our study out of 100 patients, 33 patients (33\%) were male while 67 patients (67\%) were female. 70 subjects were having sickle cell trait out of which 18 patients were male and 52 were female, whereas 30 subjects were having sickle cell disease out of which 15 patients were male and 15 were female. Mean Hb level was $8.41 \pm 1.74 \mathrm{gm} \%$. In our study population maximum $\mathrm{Hb}$ was $12 \mathrm{gm} \%$ whereas minimum $\mathrm{Hb}$ was $4 \mathrm{gm} \%$. Diastolic dysfunction was present in $50 \%$ of the total cases (100) among them $45.45 \%$ were males, $52.23 \%$ were females. Diastolic dysfunction was almost equally prevalent among female compared to male $(p=0.51)$.Mean age of women with diastolic dysfunction was $29.37 \pm 9.89 \mathrm{yrs}$, whereas mean age of men with diastolic dysfunction was $29.82 \pm 10.24$ yrs. Statistically there was no association was found between age and LVDD prevalence ( $p=0.99)$.In our study we found prevalence of LVDD in studied genotypes i.e. AS and SS to be almost similar $(P=0.62$, non-significant). Our study showed that diastolic dysfunction is more closely associated with moderate ( $\mathrm{Hb}$ level 7-10 gm\%) and severe anemia ( $\mathrm{Hb}$ level $4-7 \mathrm{gm} \%)$ than mild anemia $(\mathrm{Hb}$ level $>10 \%)$. Statistically it was found to be significant $(p=0.006)$.Mean $\mathrm{Hb}$ level of patients with diastolic dysfunction was $7.88 \pm 1.81 \mathrm{gm} \%$, whereas mean $\mathrm{Hb}$ level of patients without diastolic dysfunction was $8.94 \pm$ $1.49 \mathrm{gm} \%(P<0.01$, significant).Pulmonary Hypertension $(P H)$ was present in 24 cases $(24 \%)$ of the study population, among them 5 were males and 19 were females. There was no significant difference of prevalence of PH between both genders. ( $p=0.14)$. Out of 100 patients 12 patients (12\%) had both LVDD and PH.

Conclusion: The findings in our study indicate that in patients of sickle cell anemia, left ventricular diastolic function is impaired much before development of systolic dysfunction. Lower Hb levels in patients of sickle cell anemia is associated with cardiopulmonary complications. No significant correlation was found in respect to prevalence of PH and LVDD with age or gender. More so presence of both PH and LVDD significantly contributes to a higher mortality in patients of sickle cell anemia. Therefore by early detection we can start early treatment and can retard the progression of these cardiopulmonary abnormalities and its future consequences. Doppler Echocardiography is a simple, non-invasive, easily available technique that identifies sickle cell subjects who have asymptomatic pulmonary hypertension and/or left ventricular diastolic dysfunction much before abnormalities detected on ECG or by clinical examination. Therefore echocardiography becomes an indispensable tool for assessment of cardiac function in SCD patients.
\end{abstract}

Keywords: LVDD-Left Ventricular diastolic dysfunction, SCD-Sickle cell disease, PH-Pulmonary Hypertension, TR-Tricuspid Regurgitation

\section{Introduction}

Sickle cell disease (SCD) is an autosomal, recessive disorder characterized by a single amino acid change in the $\beta$-globin chain of the haemoglobin that results in structurally abnormal $\mathrm{HbS}$. HbS reversibly polymerizes when it is deoxygenated to form a network of fibrous polymers that stiffens the erythrocyte membrane, increases viscosity, and cause cellular dehydration due to potassium leakage and calcium influx. 
These changes produces the characteristic sickle shape of the red cells, which is less pliable leading to episodes of microvascular occlusion and premature RBC destruction,leading to haemolytic anaemia.[1] To compensate for the reduced oxygen-carrying capacity, patients often have an increased plasma volume, elevated cardiac output and enlarged heart. Cardiomegaly is an expected consequence of the anaemia of SCD.[2]

Cardiac complications are a common feature of SCD and are important cause of morbidity and mortality associated with this disease. In recent years, PH, a proliferative vascular disease of the lung, has been recognized as a major complication and an independent correlate with death among adults with SCD. For many decades, it was widely assumed that vascular occlusion by rigid red cells leading to tissue infarction was the sole cause of organ dysfunction in patients with SCD. This concept was supplemented in the late 20th century by evidence of cellular interactions between circulating blood cells and endothelial cells, suggesting dysfunction of the blood vessel wall in SCD.[3] During the last decade, it was demonstrated that chronic intravascular hemolysis may disturb nitric oxide bioavailability, promoting endothelial dysfunction, smooth muscle dystonia, enhancement of coagulopathy, and increased oxidant and inflammatory stress, all of which may lead to the development of proliferative changes seen in patients with pulmonary hypertension.[4],[5],[6] The chronic anemia of SCD results in an increased cardiac output. This results in increased stroke volume and dilation of the LV which leads to increased wall stress, increase in LV mass as well as impaired LV filling.[7] Recent studies using standard Doppler parameters and tissue Doppler have shown Diastolic dysfunction in adults and was considered as an independent risk factor for mortality.[8]

\section{Material And Methods}

The study was conducted in the Department of Medicine, Pt. Jawaharlal Nehru Memorial Medical College and Dr. B.R.A.M. Hospital, Raipur (C.G.) among the patients presenting in O.P.D. and admitted in medicine ward from Dec. 2013 to Sep. 2015. A total of 100 patients were included fulfilling the inclusion criteria for the study. Patient's informed consent was taken. Detailed clinical history was recorded including age, sex, presenting complaints, past, personal and family history. All patients underwent complete clinical examination, laboratory investigation including $\mathrm{Hb}$ Electrophoresis and Doppler Echocardiography of patients were done. Transthoracic echocardiography was performed with the use of the Mindray M7 echocardiography machine. Cardiac measurements were performed according to American Society of Echocardiography guidelines .The LV ejection fraction was assessed using M-Mode with help of "Teichholz" equations. Tricuspid regurgitation jet velocity (TRV) was assessed and pulmonary hypertension was prospectively defined as a peak TR jet velocity of at least $2.5 \mathrm{~m} / \mathrm{s}$. Diastolic function was assessed in all patients using pulse doppler peak $\mathrm{E}$ and A velocities, E/A ratio, and deceleration time.

Inclusion Criteria for study group:

1. Patients with HbSS or HbAS blood type on $\mathrm{Hb}$ electrophoresis.

2. Age group between 16 years to 70 years.

Exclusion Criteria for study group:

1. Sickle cell anemia with any preexisting cardiac including valvular heart disease.

2. Patients with primary and secondary pulmonary artery hypertension.

3.Patients with preexisting hypertension, diabetes,chronic kidney disease and LVDD.

III. Observation And Results

Total 100 cases were included in the study, out of which 33 cases (33\%) were males and $67(67 \%)$ were females. The ratio of male to female was 1: 2.03 and mean age was 29.4 years \pm 11.77 years. 70 cases (70\%) were AS and 30 (30\%) were SS genotype in the study group.

Table No. 1 - Prevalence of LV Diastolic Dysfunction according to age $(n=100)$

\begin{tabular}{|l|l|l|l|}
\hline \multirow{2}{*}{ Age(in yrs) } & \multicolumn{2}{|l|}{ LV Diastolic Dysfunction } & \multirow{2}{*}{ Grand Total } \\
\cline { 2 - 3 } & Y & N & \\
\hline $15-24$ & 21 & 21 & 42 \\
\hline $25-34$ & 16 & 13 & 29 \\
\hline $35-44$ & 5 & 8 & 13 \\
\hline $45-54$ & 6 & 4 & 10 \\
\hline $55-65$ & 2 & 4 & 6 \\
\hline Grand Total & 50 & 50 & 100 \\
\hline $\mathrm{P}=0.99$ & \multicolumn{2}{|l}{} \\
\hline
\end{tabular}


Study Of Pulmonary Hypertension And Left Ventricular Diastolic Dysfunction In Patients Of Sickle....

Table No.2 - Prevalence of Pulmonary Hypertension according to age $(\mathbf{n}=100)$

\begin{tabular}{|l|l|l|l|}
\hline \multirow{2}{*}{ Age (in yrs) } & \multicolumn{2}{|l|}{ Pulmonary Hypertension } & \multirow{2}{*}{ Grand Total } \\
\cline { 2 - 3 } & Y & N & \\
\hline $15-24$ & 13 & 29 & 42 \\
\hline $25-34$ & 4 & 25 & 29 \\
\hline $35-44$ & 3 & 10 & 13 \\
\hline $45-54$ & 1 & 9 & 10 \\
\hline $55-65$ & 3 & 3 & 6 \\
\hline Grand Total & 24 & 76 & 100 \\
\hline P value $=0.91$ & & \\
\end{tabular}

Table No.3 - Distribution of TR Velocity in study group

\begin{tabular}{|l|l|l|}
\hline \multicolumn{3}{|l|}{ Distribution of TR velocity in study population $(\mathbf{n}=\mathbf{1 0 0})$} \\
\hline TR velocity $(\mathbf{m} / \mathbf{s e c})$ & No. of patients & Mean \pm SD \\
\hline$<2.5$ & 76 & $0.76 \pm 0.98$ \\
\hline$\geq 2.5$ & 24 & $2.88 \pm 0.34$ \\
\hline Total & 100 & \\
\hline $\mathrm{P}=<0.001$ (significant) & \multicolumn{2}{|l|}{} \\
\hline
\end{tabular}

Table No.4 - Distribution of E/A value in Study group

\begin{tabular}{|l|l|l|}
\hline E/A ratio & No. of cases $(\mathbf{n}=\mathbf{1 0 0})$ & Mean \pm SD \\
\hline$<1$ & 44 & $0.9 \pm 0.48$ \\
\hline$\geq 1$ & 56 & $1.26 \pm 0.34$ \\
\hline Total & \multicolumn{2}{|l|}{100} \\
\hline$P=<0.001$ (significant)
\end{tabular}

Table No.5 - Comparison of study parameters among prevalence of diastolic dysfunction

\begin{tabular}{|c|c|c|c|c|c|c|}
\hline & \multicolumn{2}{|c|}{ LVDD Present [n=50] } & \multicolumn{2}{|c|}{ LVDD Absent [n=50] } & \multirow[b]{2}{*}{ t value } & \multirow[b]{2}{*}{ p value } \\
\hline & Mean & $\begin{array}{l} \pm \text { Std. } \\
\text { Deviation }\end{array}$ & Mean & $\begin{array}{l} \pm \quad \text { Std. } \\
\text { Deviation }\end{array}$ & & \\
\hline AGE(year) & 28.82 & 11.05 & 29.98 & 12.65 & 0.48 & 0.62 \\
\hline SBP on adm & 101.44 & 7.77 & 102.20 & 10.41 & 0.41 & 0.68 \\
\hline DBP on adm & 65.20 & 8.63 & 65.36 & 9.29 & 0.08 & 0.92 \\
\hline $\mathrm{Hb}(\mathrm{gm} \%)$ & 7.88 & 1.81 & 8.94 & 1.49 & 3.10 & 0.002 \\
\hline TLC & 9604.00 & 4927.80 & 8856.44 & 5396.60 & 0.72 & 0.47 \\
\hline UREA & 29.60 & 10.92 & 27.64 & 8.77 & 0.98 & 0.32 \\
\hline CREATININE & 0.62 & 0.53 & 0.74 & 0.53 & 1.10 & 0.25 \\
\hline T.BILIRUBIN & 1.78 & 1.06 & 1.84 & 1.30 & 0.25 & 0.81 \\
\hline QTc & 408.14 & 35.99 & 408.32 & 40.53 & 0.02 & 0.98 \\
\hline $\mathrm{E} / \mathrm{A}$ & 0.895 & 0.48 & 1.26 & 0.17 & 5.13 & 0.001 \\
\hline DclrT & 150.78 & 49.87 & 166.92 & 29.27 & 1.57 & 0.051 \\
\hline TRV & 1.17 & 1.38 & 1.66 & 1.15 & 1.70 & 0.09 \\
\hline LA SIZE & 3.10 & 0.42 & 3.10 & 0.54 & 0.00 & 0.99 \\
\hline LVEF\% & 66.46 & 8.93 & 67.14 & 7.57 & 0.41 & 0.68 \\
\hline
\end{tabular}

Table No. 6 - Comparison of study parameters among prevalence of $\mathrm{PH}$.

\begin{tabular}{|c|c|c|c|c|c|c|}
\hline & \multicolumn{2}{|c|}{ PH Absent [n=76] } & \multicolumn{2}{|c|}{ PH Present [n=24] } & \multirow[b]{2}{*}{ t value } & \multirow[b]{2}{*}{ p value } \\
\hline & Mean & $\begin{array}{l}\text { Std. } \\
\text { Deviation }\end{array}$ & Mean & $\begin{array}{l} \pm \text { Std. } \\
\text { Deviation }\end{array}$ & & \\
\hline AGE(year) & 29.55 & 11.51 & 28.92 & 13.06 & 0.28 & 0.820 \\
\hline SBP on adm & 100.47 & 8.44 & 106.08 & 10.15 & 2.70 & 0.008 \\
\hline DBP on adm & 64.16 & 8.52 & 68.83 & 9.40 & 2.28 & 0.028 \\
\hline $\mathrm{Hb}(\mathrm{gm} \%)$ & 8.58 & 1.85 & 7.88 & 1.19 & 1.70 & 0.083 \\
\hline TLC & 9127.78 & 5039.58 & 9554.63 & 5605.76 & 0.35 & 0.720 \\
\hline UREA & 28.97 & 9.94 & 27.50 & 9.93 & 0.63 & 0.520 \\
\hline CREATININE & 0.68 & 0.55 & 0.67 & 0.48 & .14 & .880 \\
\hline T.BILIRUBIN & 1.76 & 1.13 & 1.96 & 1.33 & 0.71 & 0.480 \\
\hline QTc & 399.61 & 28.28 & 435.54 & 51.25 & 4.30 & $<0.001$ \\
\hline E/A & 1.086 & 0.56 & 1.07 & 0.35 & 0.18 & 0.86 \\
\hline DclrT & 166.91 & 38.59 & 165.00 & 40.36 & 0.21 & 0.830 \\
\hline TRV & 0.76 & 0.98 & 2.88 & 0.34 & 10.20 & $<0.001$ \\
\hline LA SIZE & 3.00 & 0.43 & 3.42 & 0.50 & 3.90 & $<0.001$ \\
\hline LVEF\% & 66.89 & 8.35 & 66.50 & 8.06 & 0.21 & 0.830 \\
\hline
\end{tabular}




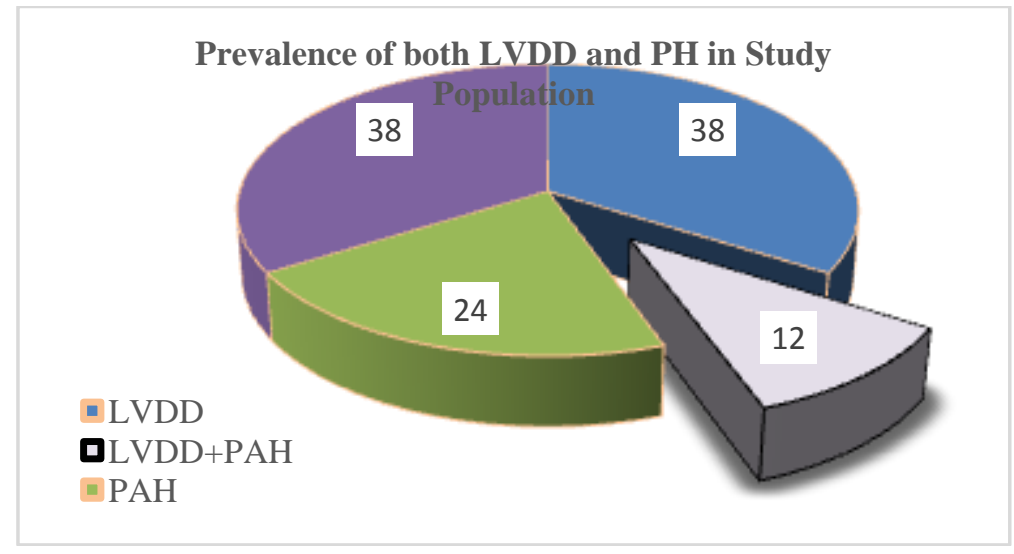

\section{Discussion}

Genotype Analysis of study: Of the 100 patients included in the study, 70 were sickle cell trait (AS) and 30 were sickle cell disease (SS).There were 18 males and 52 females of sickle cell trait and there were 15 males and 15 females of sickle cell disease.The ratio of AS to SS was 2.3:1.Majority of patients in the study were of sickle cell trait then sickle cell disease.

Age and gender wise distribution of cases in our study: Among 100 patients included in our study 33 cases $(33 \%)$ were male and 67 cases $(67 \%)$ were females. The ratio of male and female in this study group is $1: 2.03$.. The mean age of study population was 29.4 years \pm 11.77 years.

There was female preponderance in our study in every age group. Maximum number of cases were in age group of 15-24 years in our study. Pathak $\mathbf{J}$ et al studied 50 patients of sickle cell disease, in which there were 34 were male $(68 \%)$ and 16 were females (32\%). Majority of patients i.e. $23(46 \%)$ were in the age group 14-20 years, which is similar to our study.[9]In a study by Sachdev V et al out of 235 patients with documented SCD, $60 \%$ cases were female $35 \pm 11$ years as mean age. This study also shows female preponderance as our study.[8]

\section{Analysis Of Echocardiographic Findings:}

In the present study, PH was defined in patients with sickle cell anemia who had TRV $>2.5 \mathrm{~m} / \mathrm{sec}$ on echocardiography. In this study 24 patients had TR velocity $\geq 2.5 \mathrm{~m} / \mathrm{sec}$. Mean TRV in patients of group $<2.5$ $\mathrm{m} / \mathrm{sec}$ (i.e. patients with no $\mathrm{PH}$ ) was $0.76 \pm 0.98$ whereas Mean TRV in patients of group $\geq 2.5 \mathrm{~m} / \mathrm{sec}$ (i.e. patients with $\mathrm{PH}$ ) was $2.88 \pm 0.34$. This finding was statistically significant with $\mathrm{P}$ value $<0.001$.

Out of 100 patients 44 patients had $\mathrm{E} / \mathrm{A}<1$, whereas 56 patients $(56 \%)$ had $\mathrm{E} / \mathrm{A} \geq 1$. Mean value of $\mathrm{E} / \mathrm{A}=0.9 \pm$ 0.48 in patients with $\mathrm{E} / \mathrm{A}<1$, whereas mean value of $\mathrm{E} / \mathrm{A}=1.26 \pm 0.34$ in patients with $\mathrm{E} / \mathrm{A} \geq 1$. This was found to be statistically significant $(\mathrm{p}<0.001)$.

Mean Deceleration Time value in our population was $166.45 \pm 38.82 \mathrm{msec}$ with $312 \mathrm{msec}$ as minimum value and $520 \mathrm{msec}$ as maximum value.

In our study mean LVEF of study population was $66.80 \pm 8.24$. Only 9 cases $(9 \%)$ had LVEF $<55 \%$. So we can conclude that systolic function is preserved in our patients.

\section{Prevalence of LVDD in Sickle Cell study group:}

In present study, out of 100,50 patients $(50 \%)$ had Left ventricular diastolic dysfunction. Mean age of patient group with LVDD present was $28.82 \pm 11.05$ whereas patients without LVDD had mean age of $29.98 \pm 12.65$ years. Sachdev V et al assessed 141 sickle cell disease patients with the help of tissue Doppler imaging and evaluated the prevalence of diastolic dysfunction in them. They found that 25 patients $(18 \%)$ had evidence of LV diastolic dysfunction.[8] Zilberman MV et al evaluated 73 patients for diastolic dysfunction on echocardiography and found 32 had LV dilatation and 11 had hypertrophy. 43 patient $(58.9 \%)$ had left ventricular diastolic dysfunction.[10] Lewis JF and Maron et al found that 17 (57\%) of their 30 patients with sickle cell anemia had evidence of abnormal left ventricular diastolic filling. Indices of diastolic filling was obtained with pulsed doppler echocardiography. Mean age of his study group patients was 29 years which was similar and matches with our study.[11] Hankins JS, McCarville et al measured diastolic dysfunction by TDI (Tissue Doppler Imaging) in a study group of 30 sickle cell patients and found high prevalence of diastolic dysfunction i.e. 23 (77\%) of patients.[12] Eddine, Alvarez et al in their study group of 54 patients of SCD found that $31 \%$ of cases had evidence of LV diastolic dysfunction in tissue Doppler echocardiography.[13] Due to limitations arising from the techniques used, inconsistencies in the literature regarding prevalence of LV diastolic dysfunction in SCD are apparent. These limitations can be due to loading conditions, heart rate, angle 
dependency or even patient age. In SCD, increased left ventricular mass and diastolic dysfunction is associated with compensatory hypertrophy of left ventricles, secondary anemia and left ventricular dilatation along with systemic vasculopathy.

\section{Association of LVDD with Age:}

In this study majority of sickle cell disease patient i.e. 21 (50\% cases of 42) among age group of 15-24 yrs had LVDD followed by 16 (55.17\% of 29 patients) in the age group of 25-34 yrs. Mean age of men with diastolic dysfunction was $29.82 \pm 10.24$ yrs. Mean age of women with diastolic dysfunction was $29.37 \pm 9.89$ yrs. Onset of LVDD in our study population occurs at younger age group in both male and female as compared to Sachdev V et al study in which out of 235 patients with documented SCD with mean age of $35 \pm 11$ years, (range of age was 18 to 70 years) and 41 age- and gender-balanced control patients (mean age $37 \pm 11$ years)they found SCD patients with an E/A ratio of $<1.0$ were older than the remaining patients.[8] Zilberman et al in their study of 73 sickle cell patients didn't found any correlation between age and diastolic dysfunction.[10]

\section{Association between Haemoglobin (Hb) level and LVDD:}

There were 13 cases $(81.25 \%$ ) of LVDD out of 16 cases in $\mathrm{Hb}$ level group of $4-7 \mathrm{gm} \%$.Out of 74 cases of $\mathrm{Hb}$ level 7-10 gm\% 33 patients (44.59\%) had LVDD.In Hb levels of $>10 \mathrm{gm} \%$, out of 10 cases, 4 (40\%) had LVDD.So it is evident that diastolic dysfunction is associated low $\mathrm{Hb}$ levels. Mean $\mathrm{Hb}$ level in present study was $7.88 \pm 1.81 \mathrm{gm} \%$ in patients with LVDD and $8.94 \pm 1.49 \mathrm{gm} \%$ in patients without LVDD. Statistically it was found to be significant $(\mathrm{p}=0.006)$. Sachdev V et al in their study of 226 Sickle cell disease patients had LVDD, in which mean $\mathrm{Hb}$ level of $9.6 \pm 1.8 \mathrm{gm} \%$ and control group of 41 patients had mean Hb level of $13.5 \pm$ 1.6 gm\%. This clearly shows association of LVDD with low Hb levels similar to our study.[8] Raj AB, Condurache $\mathrm{T}$ in their study of 22 patients with SCD found LVDD is more prevalent in severe anemia and it was found to be statistically significant $(\mathrm{P}=.003)$. [14]

\section{Prevalence of Pulmonary Hypertension in Sickle Cell population:}

In our study 24 out of 100 sickle cell patients had PH of which 5 (20.83\%) patients were male and 19 (79.16\%) patients were female. Mean age for patients with PH was $28.92 \pm 13.06$ years and for patients without $\mathrm{PH}$ was $29.55 \pm 11.51$ years. In our study group $26.66 \%$ patients of sickle cell disease had $\mathrm{PH}$ as compared to $22.85 \%$ patients of sickle cell trait, but it was found to be statistically insignificant. Gladwin et al reported 32\% of patients had pulmonary hypertension in a study consisting of 195 patients (82 men and 113 women; mean age, $36 \pm 12$ years) of sickle cell disease. In their study they did not find any significant difference between sickle cell anemia and disease group.[15] Billy Brissac R et al reported a PH prevalence of $17 \%$ in their study of an adult population of 427 SCD patients with mean age of 37 years and mean PASP of $40 \mathrm{~mm} \mathrm{Hg.[16]} \mathrm{Ambrusko}$ et al had reported a $26 \%$ prevalence of PH in 44 patients of sickle cell anemia they studied.[17] Pashankar FD et al reported a prevalence of 30\% Pulmonary Hypertension in 62 patient with sickle cell anemia.[18] Pulmonary Hypertension was identified by 58\% patients with sickle cell anemia in a study of 38 patients in Canada by Ahmad et al. The estimated mean PASP was $37.5 \pm 10.9 \mathrm{mmHg}$.[19]Van beers EJ et al in their study of 85 patients of sickle cell anemia found a prevalence of PH in $41 \%$ patients.[20] Pathak $\mathrm{J}$ et al in their study found PH in 17(34\%) patients out of 50 patients of sickle cell anemia. All studies mentioned above used a single echocardiography method as a screening tool to diagnose PH.[9]

\section{Analysis of Pulmonary Hypertension with Age:}

There were 24 cases of PH in the study group. Mean age of women with PH was $29.37 \pm 9.89 \mathrm{yrs}$. Mean age of men with $\mathrm{PH}$ was $29.82 \pm 10.24$ yrs. Statistically it was found to be non-significant $(\mathrm{p}=0.91)$.Pathak $\mathbf{J}$ et al in a study found that advance age groups among sickle cell patient have higher prevalence for $\mathrm{PH}$. In their study $75 \%$ patients in age group of 31-40 years and $80 \%$ patients of age group $>40$ years had PH.[9] Castro O et al in a study reported that prevalence of PH increases with age in SCD patients. In $40-49$ years old prevalence was close to $40 \%$ where as it increases up to60\% by age of 50 and above.[21] Machado et al in their study stated that advance age was related to PH. In their study patients with $\mathrm{PH}$, $\mathrm{TRV}>3 \mathrm{~m} / \mathrm{sec}$ had higher age ( $38 \pm 19$ years) compared to those without $\mathrm{PH}, \mathrm{TRV}<2.5 \mathrm{~m} / \mathrm{sec}(34 \pm 10$ years). [22] The National Institute of Health PH echocardiographic screening study (Haque A K et al) showed that patients with PH were significantly older than patients without PH.[23] In our study higher prevalence i.e. 50\% among older age group ( $>55$ years old), in contrast to younger age groups which had prevalence range from 10$30.90 \%$ of $\mathrm{PH}$.

\section{Analysis of Gender and Genotype in PH group:}

In our study 24 patients had $\mathrm{PH}$ out of which 5 patients (20.83\%) were male and 19 patients (79.16\%) were female. In sickle cell trait (AS) population, 16 (22.85\%) had PH while as in sickle cell disease (SS)

DOI: $10.9790 / 0853-150723541 \quad$ www.iosrjournals.org $\quad 39 \mid$ Page


population $8(26.66 \%)$ patients had PH. Similarly Gladwin et al in their study did not find any significant differences according to gender and genotype in prevalence of pulmonary hypertension.[15] Pathak et al did not find any correlation according to gender or genotype in prevalence of pulmonary hypertension, (32\% in males and $37 \%$ in females and $33 \%$ in AS type and 35\% in SS type).[9]

\section{Analysis of Pulmonary Hypertension with degree of Anemia:}

In our study 3 (18.75\% )out of 16 cases with 4-7 gm\% Hb level had $\mathrm{PH}$ whereas in 7-10 gm\% $\mathrm{Hb}$ group 21 cases $(28.37 \%$ )out of 74 cases had PH. None of 10 cases which had Hb level between 10 to 13 had PH. Patient with PH had mean Hb level of $8.58 \mathrm{gm} \% \pm 1.85 \mathrm{gm} \%$. In our study $\mathrm{PH}$ was more prevalent in patient with moderate to severe anemia than patients with mild anemia or near normal Hb level. Statistically it was found to be insignificant $(\mathrm{p}=0.59)$. Gladwin et al in their study noted that a lower Haemoglobin level was associated with a severe degree of $\mathrm{PH}$. The mean $\mathrm{Hb}$ level of patients with $\mathrm{PH}$ was $8.5 \pm 2.0$ as compared to 9.9 \pm 1.7 in patients without it.[15] Pathak $\mathrm{j}$ et al found in their study that mean haemoglobin level was lower in the group with $\mathrm{PH}$. (mean $\mathrm{Hb}$ in Patient with $\mathrm{PH}$ was $4.49 \mathrm{gm} \%$ whereas in patient without $\mathrm{PH}$ mean $\mathrm{Hb}$ was $6.35 \mathrm{gm} \%)$.[9]

\section{Association of Pulmonary Hypertension Group with Blood Pressure:}

Gladwin et al in their study had a higher systolic blood pressure in $\mathrm{PH}$ group $123 \pm 23 \mathrm{mmHg}$ as compared to $119 \pm 15 \mathrm{mmHg}$ in patient without PH.[15] Ataga et al also found similar findings in their study.[24] Pathak $\mathrm{j}$ et al did not found much variability in PH and Non PH group in their study.[9]In our study prevalence of $\mathrm{PH}$ was found to be statistically significant ( $\mathrm{p}$ value is 0.03 ) in patients having relatively higher systolic blood pressure on admission.

\section{Prevalence of both PH and LVDD in Sickle Cell population:}

Diastolic dysfunction and pulmonary hypertension each contribute independently to prospective mortality in patients with SCD..In our study 12(12\%) patients had both LVDD and PH. Sachdev V et al in 141 patients of SCD found 11\% patients had both PH and LV diastolic dysfunction.[8] The presence of both diastolic dysfunction and pulmonary hypertension conferred a risk ratio for death of 12.0 (95\% confidence interval 3.8 to $38.1, \mathrm{p}<0.001)$.

\section{Systolic function in Sickle Cell anemia:}

In our study mean LVEF of study population was $66.80 \pm 8.24$, while in patients had PH mean LVEF was $66.50 \pm 8.06$ and in patients with LVDD mean LVEF was 66.46 \pm 8.93 . Only 9 (9\%) cases had LVEF < $55 \%$, in which 5 patients had LVDD and 3 patients found to had PH. So we can conclude that systolic function is preserved in our patients. $(\mathrm{p}=0.68$ for LVDD patients and $\mathrm{p}=0.83$ for $\mathrm{PH}$ patients, both were nonsignificant.).Sachdev V et al LV $\mathrm{n}$ their study of 235 sickle cell patients found systolic function did not impaired significantly $(\mathrm{p}=0.2)$. The average LVEF was $65 \pm 8 \%$ (range $42 \%$ to $83 \%$ ), and only $9 \%$ of patients had evidence of systolic dysfunction with an ejection fraction $<55 \%$. [8]

Batra et al found systolic function and contractility to be preserved in their study.[25] Taksande A et al in their prospective controlled study found that left ventricular contraction was good and systolic function was normal in study population.[26]

\section{Conclusion}

We conclude that SCD patients have several problems with their heart function and heart vessels. The combination of moderate-to-severe anaemia and the resultant volume load produces increased cardiac output at rest. LV mass is increased secondary to compensatory hypertrophy that occurs in response to ventricular dilation, and the severity of dilation correlates with increasing degree of anaemia. Presence of both $\mathrm{PH}$ and LVDD significantly contributes to a higher mortality in patients of sickle cell anemia. Therefore by early detection we can start early treatment and can retard the progression of these cardiopulmonary abnormalities and its future consequences. Echocardiography using the latest sophisticated ultrasound techniques is a useful and irreplaceable non-invasive technique to study the changes in cardiac structure and function in SCD patients.

\section{Acknowledgment}

The authors are grateful to authors/editors/publishers of all those articles, journals and books from where the literature for this article has been reviewed and discussed. 


\section{Bibliography}

[1]. Rees D.C., Williams, T.N. \& Gladwin, M.T. (2010) Sickle-cell disease. Lancet, 376, 2018- 2031.

[2]. Lindsay, Jr, J., Meshel, J.C. \& Patterson, R.H. (1974) The cardiovascular manifestations of sickle cell disease. Archives of Internal Medicine, 133, 643-651.

[3]. Hebbel, R.P. (1997) Adhesive interactions of sickle erythrocytes with endothelium. The Journal of Clinical Investigation, 100, S83S86.

[4]. Butrous, G., Ghofrani, H.A., and Grimminger, F. (2008). Pulmonary vascular disease in the developing world. Circulation 118, 1758-1766.Caldas, M.C., Meira, Z.A. \& Barbosa, M.M. (2008) Evaluation of 107 patients with sickle cell anemia through tissue Doppler and myocardial performance index. Journal of the American Society of Echocardiography, 21, 1163-1167.

[5]. Reiter CD, Wang X, Tanus-Santos JE, Hogg N, Cannon RO, 3rd, Schechter AN, et al. Cell-free hemoglobin limits nitric oxide bioavailability in sickle-cell disease. Nat Med. 2002;8:1383-9

[6]. Gladwin MT, Vichinsky E. Pulmonary complications of sickle cell disease. N Engl J Med.2008;359:2254-2265.

[7]. Balfour I.C., Covitz W., Davis H., Rao, P.S., Strong, W.B. \& Alpert, B.S. (1984) Cardiac size and function in children with sickle cell anemia. American Heart Journal, 108, 345-350.

[8]. Sachdev V., Machado, R.F., Shizukuda, Y., Rao, Y.N., Sidenko, S., Ernst, I., St Peter, M., Coles, W.A., Rosing, D.R., Blackwelder, W.C., Castro, O., Kato, G.J. \& Gladwin, M.T. (2007) Diastolic dysfunction is an independent risk factor for death in patients with sickle cell disease. Journal of the American College of Cardiology, 49, 472-479.

[9]. Pathak J, Vadivelan M, Mathew C.Evaluation of Cardiac Status of Sickle Cell disease Patients by 2 D Echocardiography with special reference to Pulmonary Hypertension.Indian Journal of Clinical Practice 2013;Vol.23(11): 694-697.

[10]. Zilberman MV, Young EM, Du W, et al. Pulmonary hypertension in pediatric patients with sickle cell disease: a retrospective study. Blood. 2004;104:23b.

[11]. Lewis JF, Sutton LL, Castro O, Cross DJ, Spencer JE,. Pulmonary hypertension in sickle cell disease. Am J Cardiol. 1994;74: 626628 .

[12]. Hankins JS, McCarville MB, Hillenbrand CM, Loeffler RB, Ware RE, Song R, Smeltzer MP, Joshi V. Ventricular diastolic dysfunction in sickle cell anemia is common but not associated with myocardial iron deposition. Pediatr Blood Cancer. 2010 Sep;55(3):495-500.

[13]. Eddine AC, Alvarez O, Lipshultz SE, Kardon R, Arheart K, Swaminathan S. Ventricular structure and function in children with sickle cell disease using conventional and tissue Doppler echocardiography. Am J Cardiol. 2012;109(9):1358-1364.

[14]. Raj AB, Condurache T, Bertolone S, et al. Quantitative assessment of ventricular function in sickle cell disease: effect of long-term erythrocytapheresis. Pediatr Blood Cancer. 2005;45:976-981.

[15]. Gladwin MT, Sachdev V, Jison ML, et al . Pulmonary hypertension as a risk factor for death in patients with sickle cell disease. N Engl J Med. 2004; 350 ( 9 ): 886-895 .

[16]. Billy-Brissac R, Blanchet-Deverly A, Etienne-Julan M, Foucan L. Pulmonary hypertension in an adult sickle cell population in Guadeloupe. Int J Cardiol. 2009;135(1):122-123.

[17]. Ambrusko SJ, Gunawardena S, Sakara A, et al . Elevation of tricuspid regurgitant jet velocity, a marker for pulmonary hypertension in children with sickle cell disease . Pediatr Blood Cancer . 2006 ; 47 ( 7 ): 907-913 .

[18]. Pashankar FD, Carbonella J, Bazzy-Asaad A, Friedman A. Prevalence of elevated pulmonary artery pressures in children with sickle cell disease. Pediatrics 2008 Apr; 121(4):777-782

[19]. Ahmed S, Siddiqui AK. Pulmonary manifestations of sickle cell disease. Postgrad Med J. 2003;79:384-390.

[20]. Van Beers EJ, Spronk HM, Ten Cate H, Duits AJ, Brandjes DP, van Esser JW, et al. No association of the hypercoagulable state with sickle cell disease related pulmonary hypertension. Haematologica.2008;93:e42-44

[21]. Castro O, Hoque M, Brown BD. Pulmonary hypertension in sickle cell disease: cardiac catheterization results and survival. Blood. 2003;101:1257-61.

[22]. Machado RF, Mack AK, Martyr S, Barnett C, Macarthur P, Sachdev V, et al. Severity of pulmonary hypertension during vasoocclusive pain crisis and exercise in patients with sickle cell disease. Br J Haematol. 2007;136:319-25.

[23]. Haque A K, G okhale S, R ampy B A, A degboyega P, D uarte A, Saldana MJ. Pulmonary hypertension in sickle cell haemoglobinopathy: a clinicopathologic study of 20 cases. Hum Pathol .2002; 33 ( 10 ): 1037 - 1043

[24]. Ataga KI, Moore CG, Jones S, et al. Pulmonary hypertension in patients with sickle cell disease: a longitudinal study . Br J Haematol . $2006 ; 134$ ( 1 ): 109 - 115

[25]. Batra AS, Acherman RJ, Wong W et al. Cardiac Abnormalities in children with Sickle cell Anemia. A J Hematol 2002; 70: 306312 .

[26]. Taksande A, Vilhekar K, Jain M, Ganvir B. Left ventricular systolic and diastolic functions in patients with sickle cell anemia. Indian Heart J. 2005 Nov-Dec; 57(6):694-697. 